\title{
Ontogenesis of Gastric Acid Secretion in Fetal Rat
}

\author{
BERNARD GARZON, ROBERT DUCROC, AND JEAN-PIERRE GELOSO ${ }^{(34)}$ \\ Laboratoire de Différenciation Fonctionnelle, Université Paris 7, 75221 Paris CEDEX 05, France
}

Summary

The pH of gastric fluid was measured in rat fetuses during the last 3 days of gestation. On day 19, the gastric $\mathrm{pH}$ was close to neutral. During the night of day 20, the $\mathrm{pH}$ was clearly lowered $(6.11 \pm 0.15$ units), this decrease becoming more marked on the following day. At birth (day 22), just before the first feeding, the $\mathrm{pH}$ of gastric fluid reached the mean value of $2.98 \pm 0.14$ units. This drop in gastric pH was concomitant with an increase in chloride concentration whereas the gastric $\mathrm{PCO}_{2}$ remained constant. These results imply that in term rat fetuses, the gastric mucosa secretes fixed acid, very likely hydrochloride acid.

The administration of acetazolamide (inhibitor of carbonic anhydrase) to 20-day-old fetuses did not suppress the spontaneous acidification of gastric fluid, although the enzyme activity was reduced by approximately $80 \%$. Moreover, the gastric $\mathrm{pH}$ in acetazolamide-injected fetuses was markedly lower than in the noninjected littermates. The administration of $\mathrm{NaCl}$ solution (acetazolamide vehicle) had no effect on the carbonic anhydrase activity but clearly decreased the $\mathrm{pH}$ of gastric fluid. Thus, the drop of gastric pH produced by injection of acetazolamide or saline solution alone probably results from a stress effect of puncture.

In fetuses from adrenalectomized, metopirone-treated mothers, the injection of $\mathrm{NaCl}$ solution no longer had effect on the $\mathrm{pH}$ of gastric fluid whereas triamcinolone injection produced a clear decrease in the gastric pH $3 \mathrm{hr}$ later.

\section{Speculation}

Corticosteroids could play an important role in the development of $\mathrm{H}^{+}$generation processes in parietal cells during the fetal period of life.

Electron microscopic studies have shown that in some mammals species, including man, parietal cells of the gastric mucosa begin to develop during intrauterine life $(14,15,25)$. It has been observed that gastric acid secretion takes place before birth in guinea pig (28), lamb (16), and rabbit (30). Newborn human infants have an intragastric $\mathrm{pH}$ ranging from 5.5 to 7 ; this $\mathrm{pH}$ then strongly decreases by 4 to $5 \mathrm{hr}$ of age $(1,13)$. As far as we know, there is no available information concerning the factor(s) responsible for the development of $\mathrm{H}^{+}$generation processes in parietal cells.

In rat fetuses, we have observed a sharp drop in the $\mathrm{pH}$ of the gastric content on the last day of gestation (11). Because it has been previously reported that the activity of carbonic anhydrase markedly increases near term $(15,29)$, it was tempting, as a first approach to the problem, to hypothesize a cause-effect relationship between these two events. Thus, we have studied the effect of carbonic anhydrase inhibition on the development of gastric acid secretion. We have, in addition, studied the effects of adrenalectomy and corticosteroid administration. Some of our results suggest that the adrenal gland could be implicated in the functional differentiation of parietal cells.

\section{MATERIALS AND METHODS}

ANIMALS

Sherman rats, fed a commercial diet (U.A.R., France), were used for this study. To obtain fetuses of known age, females were mated overnight. Gestation was detected by palpation 2 wk later; the day after the night of mating was considered as day zero of gestation. In this strain, delivery occurs in the night of day 21 .

\section{CHEMICAL}

Acetazolamide was purchased from Theraplix (Paris, France), and triamcinolone was purchased from Sigma Chemical Co. (Saint Louis, MO). Metopirone was a gift of the Ciba laboratory, (Basel, Switzerland).

\section{EXPERIMENTAL PROCEDURES}

Pregnant rats were adrenalectomized under ether anaesthesia on day 16 of gestation and then received $10 \mathrm{mg}$ metopirone by intraperitoneal injections twice a day until the time of sacrifice. Such treatment suppresses, or at least strongly reduces, the circulating corticosteroids in fetal blood (10). The effectiveness of this treatment in fetuses is indicated by the enlargement (compensatory hypertrophy) of fetal adrenal glands as shown in Tables 3 and 4.

Acetazolamide and triamcinolone were administered at doses of 100 and $20 \mu \mathrm{g}$, respectively, in $20 \mu \mathrm{l} 0.15 \mathrm{M} \mathrm{NaCl}$ per fetus. Some fetuses ( $\mathrm{NaCl}$-injected fetuses) were given injections of 20 $\mu \mathrm{l}$ of the $\mathrm{NaCl}$ solution alone. Subcutaneous injections into fetuses were done through the uterine wall after laparotomy of the mother under light ether anesthesia.

\section{pH AND $\mathrm{PCO}_{2}$ DETERMINATIONS}

At the time of sacrifice, pregnant rats were laparotomized under pentobarbital anaesthesia. Samples of amniotic fluid, fetal blood, and fetal gastric fluid were collected into type D 551 capillary tubes (Radiometer, Copenhagen, Denmark), avoiding any air bubbles. Determinations of $\mathrm{pH}$ and $\mathrm{PCO}_{2}$ were immediately done at $37^{\circ} \mathrm{C}$ using a Blood Micro System 3 Radiometer apparatus.

\section{CHLORIDE DETERMINATION}

The concentration of chloride in fluid samples was measured by potentiometric titration with silver nitrate (27) using a silver electrode PK 499 (Radiometer) connected to a TTT 2 Radiometer titrator and an autoburette ABU 12 (Radiometer) filled with 0.1 $\mathrm{M} \mathrm{AgNO}$ solution.

\section{CARBONIC ANHYDRASE ASSAY}

Stomachs were excised from fetuses, cut open along the visceral axis, washed in ice-cold distilled water, and weighed. Whole stomachs were homogenized (Potter Teflon-glass homogenizer) in distilled water. The proportion of homogenizing solution to tissue being $30 / 1(\mathrm{v} / \mathrm{w})$, it was necessary to pool stomachs of three to six 


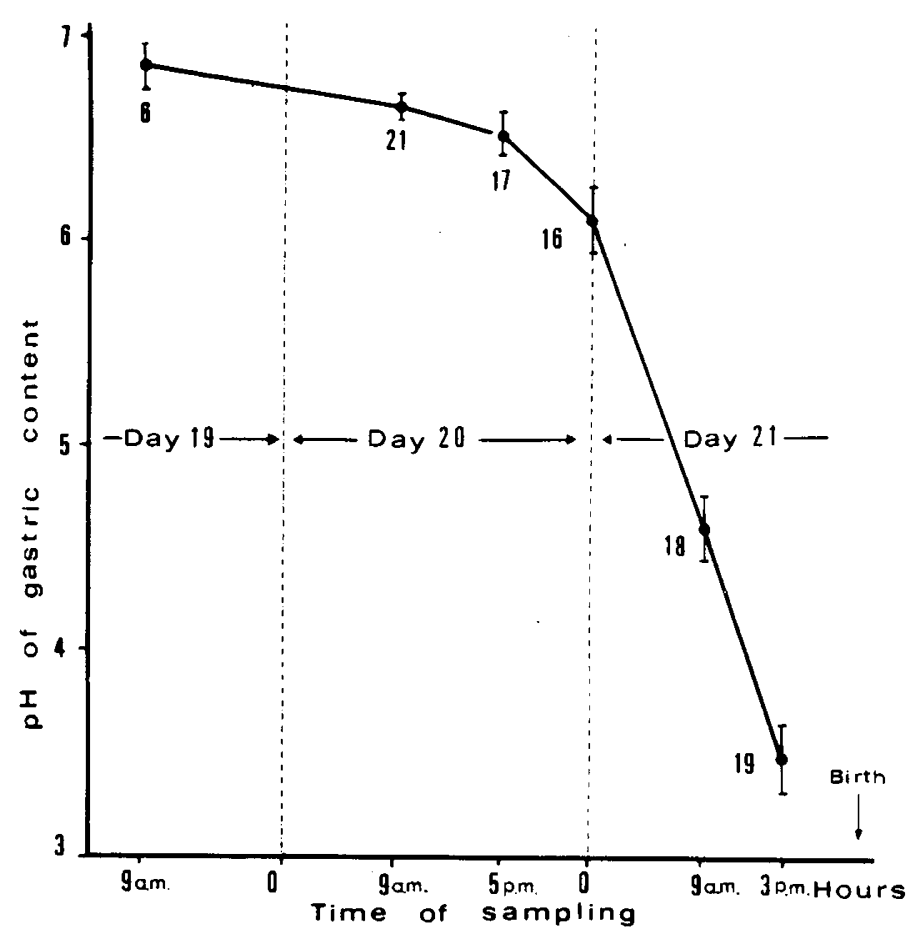

Fig. 1. Evolution of the $\mathrm{pH}$ of fetal rat gastric fluid on the last 3 days of gestation. Mean \pm standard error (vertical bars) with number of experiments. $\mathrm{pH}$ determinations were done at $37^{\circ} \mathrm{C}$ in anaerobic conditions.

fetuses according to their age. The homogenate was squeezed through a double layer of gauze; part of this suspension was used for protein determination (22). Protein concentration in the homogenate was approximately $600 \mu \mathrm{g} \cdot \mathrm{ml}^{-1}$; preliminary experiments have shown that the hydration reaction was linear for concentrations ranging from 150 to $1000 \mu \mathrm{g} \cdot \mathrm{ml}^{-1}$.

The activity of carbonic anhydrase (EC 4.2.1.1) was assessed by measuring the rate of hydration of carbon dioxide following the pH-stat method described by Hansen and Magid (12) with slight modifications. The reaction chamber (a polyethylene cupel) was filled with $2.5 \mathrm{ml}$ of Sørensen phosphate buffer, (pH 7.2) and 0.5 $\mathrm{ml}$ of either gastric homogenate or buffer solution for determination of the rate of the uncatalized reaction. The reaction was started by introducing a gas mixture $\left(10 \% \mathrm{CO}_{2}, 90 \% \mathrm{~N}_{2}\right)$ at a flow rate of $300 \mathrm{ml} \cdot \mathrm{min}^{-1}$ into the medium, temperature being maintained at $4^{\circ} \mathrm{C}$ by a circulating refrigerant. The $\mathrm{pH}$ was measured by a combised glass-calomel electrode (GK 230, Radiometer) connected to the TTT 2 titrator and held at the constant value of 7.2 units by addition of $0.05 \mathrm{M} \mathrm{NaOH}$ solution automatically delivered by the ABU 12 autoburette. Measurements were carried out for a period of 2 min during which the rate of hydration reaction was linear. Results were expressed as $\mu$ moles of $\mathrm{H}^{+}$ produced per $\mathrm{mg}^{-1}$ protein per minute $\left(\mu\right.$ moles $\mathrm{H}^{+} \cdot \mathrm{mg}^{-1}$ Prot. $\min ^{-1}$ ); the activity of the carbonic anhydrase is the difference between the rates of $\mathrm{H}^{+}$production in the presence and in the absence (uncatalyzed reaction) of homogenate.

Although fetuses were carefully bled, traces of blood were present in the gastric homogenate. A correction for the carbonic anhydrase activity due to the presence of erythrocytes was made by measuring the concentration of haemoglobin (5) in the homogenate and the carbonic anhydrase activity per mg haemoglobin in fetal erythrocytes.

All data are presented as means \pm S.E. and evaluated for significance by the unpaired Student $t$ test.

\section{RESULTS}

SPONTANEOUS ACIDIFICATION OF THE GASTRIC CONTENT IN FETAL RAT

As shown in Figure 1, between the morning of day 19 and the afternoon of day 20 , there was a slight, but not significant, decrease in the gastric $\mathrm{pH}(6.85 \pm 0.09$ and $6.52 \pm 0.11 ; P>0.05)$. During the night of day 20 , the $\mathrm{pH}$ was clearly lowered $(6.11 \pm 0.15)$, this decrease becoming more marked on the following day (day 21). At birth, just before the first feeding, the $\mathrm{pH}$ of gastric fluid reached the mean value of $2.98 \pm 0.14$ units.

Between days 19 and 21 , the acidification of the gastric fluid was associated with a clear increase in the chloride ion concentration (Table 1). During this period, the $\mathrm{pH}$ and chloride concentration in blood plasma and amniotic fluid remained constant. In addition, there was no change in the $\mathrm{PCO}_{2}$ of gastric fluid which was close to that of blood.

\section{DEVELOPMENT OF THE GASTRIC CARBONIC ANHYDRASE ACTIVITY IN FETAL STOMACHS}

As shown in Figure 2, no carbonic anhydrase activity was observed in the gastric tissue homogenate on days 17 and 18. A very low but significant activity appeared for the first time on day 19: $8.0 \pm 1.6 \mu$ moles $\mathrm{H}^{+} \cdot \mathrm{mg}$ Prot. $^{-1} \cdot \mathrm{min}^{-1}$. From this day, the carbonic anhydrase activity rose, reaching a level five times higher on the last day of gestation: $37.2 \pm 5.0 \mu$ moles $^{+} \cdot \mathrm{mg} \mathrm{Prot.}^{-1}$. $\min ^{-1}$.

\section{EFFECT OF ACETAZOLAMIDE ON THE ACIDIFICATION OF GASTRIC} FLUID

A single dose of acetazolamide was injected in the evening of day 20. Sampling was done $16 \mathrm{hr}$ later in the morning (10:00 AM) of day 21. This treatment strongly inhibited the gastric carbonic anhydrase activity $(-75 \%)$ in both acetazolamide-injected fetuses and noninjected littermates, meaning that the enzyme inhibitor easily diffuses from the injected fetuses to the others (Table 2). The level of enzyme activity in acetazolamide-treated litters was close to that observed in 19-day-old fetuses.

Surprisingly, the gastric $\mathrm{pH}$ in the acetazolamide-injected fetuses was markedly lower than in the noninjected littermates. In

Table 1. $\mathrm{pH}, \mathrm{PCO}_{2}$ and $\mathrm{Cl}^{-}$concentration in fetal blood plasma and gastric and amniotic fluids on the last 3 days of gestation ${ }^{1}$

\begin{tabular}{cccc}
\hline $\begin{array}{c}\text { Day of } \\
\text { gestation }\end{array}$ & Gastric content & Blood plasma & Amniotic fluid \\
\hline 19 & & & \\
$\mathrm{pH}$ & $6.85 \pm 0.09^{2}$ & $7.27 \pm 0.02$ & $7.25 \pm 0.02$ \\
& $(6)^{3}$ & $(5)^{4}$ & $(6)^{4}$ \\
$\mathrm{Cl}^{-}$ & $104.9 \pm 1.2$ & $101.5 \pm 0.5$ & $104.0 \pm 0.4$ \\
& $(7)$ & $(5)^{4}$ & $(6)$ \\
20 & & & \\
$\mathrm{pH}$ & $6.66 \pm 0.04$ & $7.26 \pm 0.03$ & $7.26 \pm 0.01$ \\
& $(19)$ & $(9)^{4}$ & $(7)^{4}$ \\
$\mathrm{Cl}^{-}$ & $114.4 \pm 2.0$ & $99.2 \pm 1.6$ & $102.4 \pm 3.3$ \\
& $(20)^{5}$ & $(10)^{4}$ & $(9)^{4}$ \\
$\mathrm{PCO}_{2}$ & $61.9 \pm 3.0$ & $64.7 \pm 1.7$ & \\
& $(15)$ & $(17)$ & \\
& & & $(7)^{4}$ \\
21 & $4.61 \pm 0.15$ & $7.29 \pm 0.01$ & $7.26 \pm 0.01$ \\
$\mathrm{pH}$ & $(21)^{5}$ & $(6)^{4}$ & $(101.1 \pm 3.3$ \\
$\mathrm{Cl}^{-}$ & $138.5 \pm 1.9$ & $99.5 \pm 1.6$ & $(9)^{4}$ \\
& $(19)^{5}$ & $(10)^{4}$ & \\
$\mathrm{PCO}_{2}$ & $60.7 \pm 2.2$ & $62.0 \pm 1.7$ & $(16)$ \\
& $(10)$ & $(10)$ &
\end{tabular}

${ }^{1} \mathrm{PCO}_{2}$ is expressed as $\mathrm{mm} \mathrm{Hg}$ and $\mathrm{Cl}^{-}$concentration as mmoles $1^{-1}$. All animals were sacrificed at $10: \mathrm{AM} ; \mathrm{pH}$ and $\mathrm{PCO}_{2}$ determinations were done in anaerobic conditions at $37^{\circ} \mathrm{C}$.

${ }^{2}$ Mean \pm S.E.

${ }^{3}$ Numbers in parenthesis, number of experiments.

${ }^{4}$ Differences from gastric fluid values statistically significant $(P<0.05)$.

${ }^{5}$ Differences from the preceding day of gestation statistically significant $(P<0.05)$. 


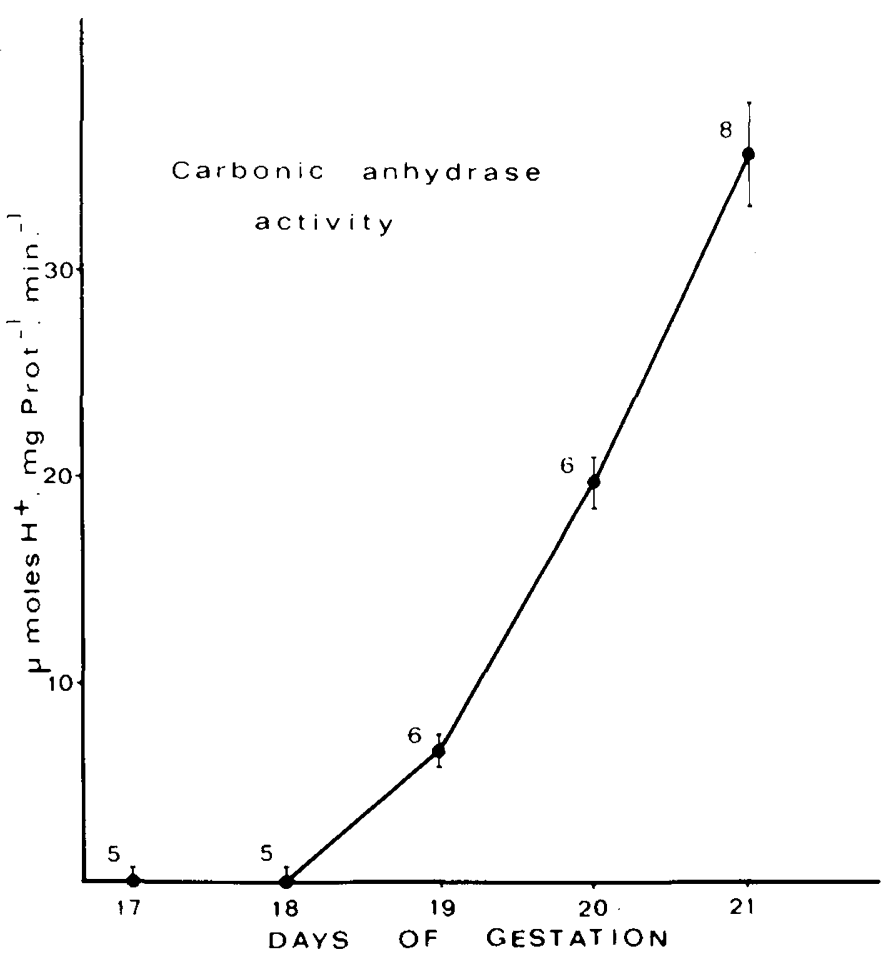

Fig. 2. Development of carbonic anhydrase activity in fetal stomach. Mean \pm standard error with number of experiments. Enzyme activity corrected for blood contamination (see "Material and Methods") is expressed as $\mu$ moles $\mathrm{H}^{+}$per $\mathrm{mg}$ of protein per minute.

\section{Table 2. Effect of carbonic anhydrase inhibition on the $p H$ of} gastric fluid in 21-day-old fetuses

\begin{tabular}{|c|c|c|}
\hline Treatment of fetuses ${ }^{1}$ & $\begin{array}{c}\text { Carbonic } \\
\text { anhydrase } \\
\text { activity }\end{array}$ & Gastric $\mathrm{pH}$ \\
\hline Acetazolamide injected & $\begin{array}{c}9.2 \pm 2.7^{2} \\
(5)^{3,4}\end{array}$ & $\begin{array}{c}3.46 \pm 0.26 \\
(5)^{5}\end{array}$ \\
\hline Noninjected & $\begin{array}{c}9.2 \pm 4.3 \\
(5)^{4}\end{array}$ & $\begin{array}{c}5.18 \pm 0.47 \\
(5)\end{array}$ \\
\hline $\mathrm{NaCl}$ injected & $\begin{array}{c}39.8 \pm 2.6 \\
\text { (7) }\end{array}$ & $\begin{array}{c}3.97 \pm 0.15 \\
(8)^{5}\end{array}$ \\
\hline Noninjected & $\begin{array}{c}40.0 \pm 1.9 \\
(7)\end{array}$ & $\begin{array}{c}4.85 \pm 0.20 \\
(8)\end{array}$ \\
\hline Controls & $\begin{array}{c}37.2 \pm 0.8 \\
\quad(5)\end{array}$ & $\begin{array}{c}4.80 \pm 0.20 \\
\quad(10)\end{array}$ \\
\hline
\end{tabular}

${ }^{1}$ During the evening of day 20 , mothers were laparotomized under light ether anaesthesia, and fetuses were given injections of either $100 \mu \mathrm{g}$ of acetazolamide in $20 \mu \mathrm{l}$ of $0.15 \mathrm{M} \mathrm{NaCl}$ or the saline solution alone (vehicle); animals were sacrificed $16 \mathrm{hr}$ later (day 21; 10:00 AM). Noninjected animals are fetuses from the same litters as those given injections; controls are fetuses from nonlaparotomized mothers.

${ }^{2}$ Mean \pm S.E. Activity of carbonic anhydrase $\left(\mu \mathrm{mol} \mathrm{H} \mathrm{H}^{+} \cdot \mathrm{mg}^{-1}\right.$ Prot. $\left.\min ^{-1}\right)$ is corrected for blood contamination.

${ }^{3}$ Numbers in parentheses, number of experiments.

${ }^{4}$ Differences from controls or $\mathrm{NaCl}$-injected litters are statistically significant $(P<0.001)$.

${ }^{5}$ Differences from controls or noninjected fetuses are statistically significant $(P<0.001)$.

the latter, the mean gastric $\mathrm{pH}$ value did not significantly differ from that found in fetuses from nonlaparot mized mothers sacrificed at the same time (controls). The administration of $\mathrm{NaCl}$ solution (acetazolamide vehicle) had no effect on the carbonic anhydrase activity but clearly decreased the $\mathrm{pH}$ of gastric fluid.
There was no significant difference between the $\mathrm{pH}$ values in acetazolamide and $\mathrm{NaCl}$-injected fetuses.

\section{ROLE OF CORTICOSTEROIDS}

In the 20-day-old fetuses from adrenalectomized, metopironetreated mothers, $\mathrm{NaCl}$ injection had no effect on the $\mathrm{pH}$ of gastric fluid when compared with that of noninjected fetuses of the same litter, whereas triamcinolone clearly decreased the gastric $\mathrm{pH}$. In both fetuses from sham-adrenalectomized mothers and controls, the injection of $\mathrm{NaCl}$ alone decreased the gastric $\mathrm{pH}$ (Table 3). On day 21 , the lack of circulating corticosteroids produced a retardation of the spontaneous acidification of gastric fluid without any significant change in the carbonic anhydrase activity (Table 4).

\section{DISCUSSION}

The stomach of near-term rat fetuses is filled with a liquid (approximately $30 \mu \mathrm{l}$ ) which mainly originates from swallowed amniotic fluid $(11,21)$. Because there is no change in the composition of amniotic fluid during the last days of gestation, the drop in $\mathrm{pH}$ concomitant with an increase in chloride concentration occurring in fetal stomach must reflect the onset of physiologic

Table 3. Effects of $\mathrm{NaCl}$ and triamcinolone injections on the gastric $\mathrm{pH}$ in 20-day-old fetuses from adrenalectomized, metopirone-treated mothers

\begin{tabular}{ccc}
\hline Treatment $^{1}$ & Gastric $\mathrm{pH}$ & $\begin{array}{c}\text { Adrenal } \\
\text { gland } \\
\left(\mathrm{mg} \cdot 100 \mathrm{~g}^{-1}\right. \\
\text { body wt })\end{array}$ \\
&
\end{tabular}

Fetuses from adrenalectomized metopirone-treated mothers

Triamcinolone injected

$\mathrm{NaCl}$ injected

Noninjected

$\begin{array}{ll}5.92 \pm 0.12^{2} & \\ (10)^{3,4} & \\ 6.76 \pm 0.06 & 109.1 \pm 3.6 \\ (10)^{5} & (20)^{6}\end{array}$

$6.85 \pm 0.06$

Fetuses from sham adrenalectomized mothers

$\mathrm{NaCl}$ injected

$6.16 \pm 0.06$
$(9)^{7}$
$6.84 \pm 0.04$

$67.5 \pm 5.4$

Noninjected

Controls

$\mathrm{NaCl}$ injected

$$
\begin{gathered}
6.12 \pm 0.09 \\
(11)^{7} \\
6.83 \pm 0.08 \\
(12)
\end{gathered}
$$

$64.7 \pm 4.3$

\footnotetext{
${ }^{1}$ Pregnant rats were adrenalectomized on day 16 of gestation and received $10 \mathrm{mg}$ metopirone twice a day until sacrifice (day 20). Three $\mathrm{hr}$ before sampling, some fetuses received by subcutaneous injection either $20 \mu \mathrm{g}$ triamcinolone in $20 \mu \mathrm{l}$ of $0.15 \mathrm{M} \mathrm{NaCl}$ solution or $20 \mu \mathrm{l}$ of $\mathrm{NaCl}$ solution alone $(\mathrm{NaCl}$ injected). Noninjected animals are fetuses from the same litters as $\mathrm{NaCl}$-injected ones. Controls are fetuses from nonadrenalectomized mothers sacrificed at the same time as those from adrenalectomized or sham-operated mothers.

${ }^{2}$ Mean \pm S.E.

${ }^{3}$ Numbers in parentheses, number of experiments.

${ }^{4}$ Differences from $\mathrm{NaCl}$-injected or noninjected fetuses statistically significant $(P<0.01)$

${ }^{5}$ Differences from $\mathrm{NaCl}$ injected of sham-operated or control groups statistically significant $(P<0.01)$.

${ }^{6}$ Differences from sham-operated or control groups statistically significant $(P<0.001)$.

${ }^{7}$ Differences from noninjected statistically significant $(P<0.01)$.
} 
Table 4. Effect of maternal adrenalectomy and metopirone administration on the gastric $\mathrm{pH}$ and carbonic anhydrase activity in 21-dayold fetuses

\begin{tabular}{lccc}
\hline \multicolumn{1}{c}{ Treatment $^{1}$} & Gastric $\mathrm{pH}$ & $\begin{array}{c}\text { Carbonic anhydrase } \\
\text { activity }\end{array}$ & $\begin{array}{c}\text { Adrenal gland wt } \\
\left(\mathrm{mg}^{1} \cdot 100 \mathrm{~g}^{-1} \text { body wt }\right)\end{array}$ \\
\hline $\begin{array}{l}\text { Fetuses from adrenalectomized, metopirone-treated } \\
\text { mothers }\end{array}$ & $5.81 \pm 0.18^{2}(12)^{3,4}$ & $35.5 \pm 1.3(9)^{5}$ & $106.2 \pm 3.9(13)^{5}$ \\
Fetuses from sham adrenalectomized mothers & $4.21 \pm 0.16(10)$ & $38.9 \pm 2.1(7)$ & $69.1 \pm 0.3(10)$ \\
Controls & $4.31 \pm 0.10(9)$ & $40.7 \pm 1.7(9)$ & $63.7 \pm 0.3(9)$ \\
\hline
\end{tabular}

\footnotetext{
' Pregnant rats were adrenalectomized on day 16 of gestation and received $10 \mathrm{mg}$ metopirone twice a day until sacrifice (day 21 at 10:00 AM). Controls are fetuses from nonadrenalectomized mothers sacrificed at the same time as those from adrenalectomized or sham operated mothers. Animals were sacrificed in the morning of day 21 (10:00 AM).

${ }^{2}$ Mean \pm S.E.

${ }^{3}$ Numbers in parenthesis, number of experiments.

${ }^{4}$ Differences from sham operated or controls statistically significant $(P<0.001)$.

${ }^{5}$ No significant difference from sham operated or controls.
}

activity of the gastric mucosa. The fact that gastric $\mathrm{PCO}_{2}$ remains constant implies that fixed acid, very likely hydrochloric acid, is secreted. We have recently presented in a short abstract (8) direct in vitro evidence for the presence of an active $\mathrm{H}^{+}$transport by the stomach of 20- to 21-day-old rat fetuses. Our results are in opposition to data in the literature $(15,16,23,32)$ which report that the $\mathrm{pH}$ of gastric content in near-term fetuses and newborns is close to neutral. Such a discrepancy is probably due to the use by previous investigators of inadequate techniques for measuring $\mathrm{pH}$ with sufficient accuracy in such small amounts of fluid. Differentiated parietal cells appear for the first time in gastric mucosa of rat fetuses on day 19 of gestation (15) and acquire the capacity to secrete acid some hours later (present data). Thus, the close relationship between ultrastructural and functional differentiation of parietal cells previously observed in the rabbit $(14$ 30 ) is also found in the rat. In man, typical gastric parietal cells have been observed from the fifth month of gestation (25), but the relatively high $\mathrm{pH}$ values observed at birth (1) does not allow to establish such a relationship.

In adult stomach, the role of carbonic anhydrase which catalyzes the generation of $\mathrm{H}^{+}$from $\mathrm{CO}_{2}$ is not clearly defined (7). It was noted that carbonic anhydrase activity increases after stimulation of gastric secretion, in rat $(24,26)$ and guinea pig stomach $(19)$ The effects of enzyme inhibitors on the rate of acid secretion are controversial. Administration of acetazolamide to histamine-stimulated dogs markedly decreases acid secretion (18). However, the carbonic anhydrase inhibitor does not modify the in vitro production of $\mathrm{H}^{+}$by isolated gastric mucosa of rabbits (9). During fetal life, gastric carbonic anhydrase activity has been observed in man (2) and rat (15). In the latter (present data), we did not find any cause-effect relationship between the increase of carbonic anhydrase activity and the appearance of acid secretion. The spontaneous acidification of gastric content occurred normally in acetazolamide-treated fetuses, although carbonic anhydrase activity was reduced by approximately $80 \%$; moreover, the secretion of acid could be prematurely induced by injection of saline solution in spite of the very low activity of enzyme. The small residual activity of carbonic anhydrase might be sufficient to sustain acid production, and it would be interesting to obtain a complete inhibition of enzyme, but higher doses of acetazolamide appeared to be lethal for fetuses. In any case, our results clearly indicate that the rapid development of the activity of carbonic anhydrase is not a limiting factor for the installation of acidifying processes in gastric mucosa of fetal rats.

The drop in gastric $\mathrm{pH}$ produced by the injection of acetazolamide or saline solution probably results from "a stress effect of puncture." Inasmuch as this effect was no longer observed in fetuses from adrenalectomized, metopirone-treated mothers and triamcinolone was able to stimulate the gastric acid secretion in these fetuses, one may think that an increase in the level of circulating endogenous corticosteroids may account for this so- called stress effect of puncture. Corticosterone has been detected in the plasma of fetal rats, the highest hormone level being found on day 19 of gestation $(4,17)$. More recently, the presence of specific glucocorticoid receptors has been demonstrated in the cytosol of fetal stomach (20). Yeomans et al. (31) have shown in cultured fetal rat stomach that cortisol promotes the cytologic differentiation and maturation of gastric mucosa. Therefore, the high gastric $\mathrm{pH}$ that we have observed on day 21 in fetuses from adrenalectomized, metopirone-treated mothers could have been caused by a delayed organogenesis of gastric mucosa. However, this trophic effect of steroids could not explain the rapidity of the response of fetal stomach $(3 \mathrm{hr})$ injection of triamcinolone. Such a short-term effect of corticosteroids on the acidification of gastric content seems more compatible with a stimulation of $\mathrm{H}^{+}$generation processes in already differentiated parietal cells than with a corticosteroid-induced architectural maturation of the mucosa. In the adult, it is generally recognized that corticosteroids are necessary for the maintenance of normal gastric acid secretion; adrenalectomy leads to a marked fall in acid concentration of the gastric juice (3). However, results concerning the effect of corticosteroid treatment are conflicting; some authors have observed an increased acid secretion whereas others fail to obtain any evidence of a rise in the gastric acid secretion (6). Our own results strongly suggest that corticosteroids play a role in the development of $\mathrm{H}^{+}$generation processes in parietal cells during the fetal period of life, and it would be interesting to know whether corticoids act directly on parietal cells or undirectly by the way of stimulating factors as histamine, gastrin, or others (?).

\section{REFERENCES AND NOTES}

1. Avery, G. B., Randolph, J. G., and Weaver, T.: Gastric activity in the first day of life. Pediatrics, 37: 1005 (1966)

2. Berfenstam, R.: Carbonic anhydrase activity in fetal organs. Acta Pediatr., 4l: 310 (1952).

3. Bralow, S. P., Komarov, S. A., and Shay, H.: Effect of total adrenalectomy on gastric secretion in chronic fistula rats. Am. J. Physiol., 206: 1309 (1964).

4. Cohen, A.: Plasma corticosterone concentration in the foetal rat. Horm. Metab. Res., 5: 66 (1973).

5. Crosby, W. H., and Furth, F. W.: A modification of the benzidine method for measurement of hemoglobin in plasma and urine. Blood J. Hematol., 11:380 (1956).

6. Domschke, W., Domschke, S., Huber, W., and Demling, L.: Glucocorticoid and mineralocorticoid actions on gastric secretion in man. Acta Hepato-Gastroenterol., 24: 34 (1977).

7. Dousa, T. P., and Dozois, R. R.: Interrelationship between histamine, prostaglandins and cyclic AMP in gastric secretion: a hypothesis. Gastroenterology, 73: 904 (1977).

8. Ducroc, R., Desjeux, J. F., Garzon, B., and Geloso, J. P.: Development of active $\mathrm{H}^{+}$secretion in foetal rat stomach. 13th annual meeting. European Society for Paediatric Gastroenterology. Capri, May, 1980.

9. Fromm, D., Schwartz, J. H., and Quijano, R.: Transport of $\mathrm{H}^{+}$and other electrolytes across isolated gastric mucosa of the rabbit. Am. J. Physiol., 228 166 (1975).

10. Geloso, J. P., and Basset, J. C.: Role of adrenal glands in development of foetal rat kidney Na-K ATPase. Pflügers Arch. Eur. J. Physiol., 348: 105 (1974). 
11. Geloso, J. P., Garzon, B., and Vassout, P.: Sécrétion d’acide chlorhydrique par la muqueuse gastrique due foetus de rat. C. R. Acad. Sci., 283: 1209 (1976)

12. Hansen, P., and Magid, E.: Studies on a method of measuring carbonic anhydrase activity. J. Clin. Invest., 18: 21 (1966).

13. Harries, J. T., and Fraser, A. J.: The activity of the gastric contents of premature babies during the first fourteen days of life. Biol. Neonat., 12: 186 (1968).

14. Hayward, A. F.: The ultrastructure of developing gastric parietal cells in the foetal rabbit. J. Anat., 101: 69 (1967).

15. Helander, H. F.: Ultrastructure and function of gastric parietal cells in the rat during development. Gastroenterology. 56: 35 (1969).

16. Hill, K. J.: Gastric development and antibody transference in the lamb, with some observations in the rat and guinea-pig. Q. J. Exp. Physiol. Cogn. Med. Sci., 41: 421 (1956).

17. Holt, P. G., and Oliver, I. T.: Plasma corticosterone concentrations in the perinatal rat. Biochem. J., 108: 339 (1968).

18. Janowitz, H. D., Colcher, H., and Hollander. F.: Inhibition of gastric secretion in dogs by carbonic anhydrase inhibitor: 2-acetylamine 1,3,4-thiadiazole 5 sulfanomide. Am. J. Physiol., 171: 325 (1952).

19. Klaff, L. J., Vinik, A. I., and Helsinger, A.: The interaction between gastrin and histamine on the activation of carbonic anhydrase in guinea-pig parietal cells. Gastroenterology, 76: 1171 (1979)

20. Lentze, M. J.. and Trier, J. S.: Cytoplasmic glucocorticoid receptors in stomach and intestine of developing rats. Twelfth Annual Meeting. European Society for Paediatric Gastroenterology. London. May 1979.

21. Lev, R., and Orlic, D.: Protein absorption by the intestine of the fetal rat utero. Science (Wash. D. C.), 177: 522 (1972).

22. Lowry, O. H., Rosebrough, N. J., Farr, A. L., and Randall, R. J.: Protein measurement with the Folin phenol reagent. J. Biol. Chem., 193: 265 (1951).

23. Manville, I. A., and Lloyd, R. W.: The hydrogen ion concentration of the gastric juice of fetal and newborn white rats. Am. J. Physiol., 100: 394 (1932)

24. Narumi. S., and Maki, Y.: Possible role of cyclic AMP in gastric acid secretion in rat. Activation of carbonic anhydrase. Biochim. Biophys. Acta, 311: 90 (1973).

25. Nomura, Y.: On the submicroscopic morphogenesis of parietal cells in the gastric gland of the human fetus. Z. Anat. Entwicklungsgesch., 125: 316 (1966).

26. Salganik, R. I., Argutinskava, S. V., and Bersimbaev, R. I.: The stimulating action of gastrin pentapeptide, histamine and cyclic adenosine $3^{\prime}, 5^{\prime}$-monophosphate on carbonic anhydrase in rat stomach. Experientia, 28: 1190 (1972).

27. Sanderson, P. H.: Potentiometric determination of chloride in biological fluids Biochem. J., 52: 502 (1952).

28. Sutherland, G. F.: Contributions to the physiology of the stomach. Am. J. Physiol., 55: 398 (1921).

29. Vollrath, L.: Uber Entwicklung und Funktion der Belegzellen der Magendrüssen. Z. Zellforsch. Mikrosk., 50: 36 (1959).

30. Wright, G. H.: Net transfers of water, sodium, chloride and hydrogen ions across the gastric mucosa of the rabbit foetus. J. Physiol (Lond.), 163: 281 (1963).

31. Yeomans, N. D., Trier, J. S., Moxey, P. C., and Markezin, E. T.: Maturation and differentiation of cultured fetal stomach. Gastroenterology, 7l: 770 (1976)

32. Zelenkova, J.. and Gregor, O.: Development of gastrin activity. Scand. J. Gastroenterol.. 6: 653 (1971).

33. The authors thank M. F. Bedel for her excellent secretarial assistance.

34. Requests for reprints should be addressed to: J. P. Geloso, Laboratoire de Différenciation Fonctionnelle, Université Paris 7, 2 Place Jussieu 7522l Paris CEDEX 05. France.

35. This research was supported by a grant from I.N.S.E.R.M. (ATP 5678 88)

36. Received for publication July 15, 1980.

37. Accepted for publication October $28,1980$. 